CHRONIC ILLNESS IN THE UNITED STATES

Chronic Illness in a Rural Area 



\section{COMMISSION ON CHRONIC ILLNESS}

June 1949-June 1956

AN INDEPENDENT NATIONAL AGENCY TO STUDY

THE PROBLEMS OF CHRONIC DISEASE,

ILLNESS, AND DISABILITY

\section{FOUNDERS}

American Hospital Association

American Medical Association

american Public Health Association

american Public Welfare Association 


\section{A STUDY OF THE PREVALENCE OF CHRONIC ILLNESS AND NEEDS FOR CARE IN A RURAL AREA}

\section{Conducted by}

The Hunterdon Medical Center

with assistance from

The National Opinion Research Center

The State of New Jersey Department of Health

Supported by grants from

The Commonwealth Fund

and sponsored by

The Commission on Chronic Illness 


\title{
CHRONIC ILLNESS IN
}

\section{THE UNITED STATES}

VOLUME III

\section{Chronic Illness in a Rural Area}

\section{The Hunterdon Study}

\author{
REPORTED BY \\ RaY E. Trussell, M.D., M.P.H. \\ Chairman, School of Public Health and Administrative Medicine, \\ Columbia University \\ Formerly Director, Hunterdon Medical Center, Flemington, N.J. \\ JACK ELINSON, PH.D. \\ Associate Professor, School of Public Health and Administrative Medicine, \\ Columbia University \\ Formerly Senior Study Director, National Opinion Research Center, \\ Chicago, Ill.
}

Published for The Commonwealth Fund

BY HARVARD UNIVERSITY PRESS

Cambridge, Massachusetts 
(C) 1959 BY THE COMMONWEALTH FUND

\author{
Published for \\ The Commonwealth Fund \\ By Harvard University Press \\ Cambridge, Massachusetts
}

For approximately a quarter of a century THE COMMONWEALTH FUND, through its Division of Publications, sponsored, edited, produced, and distributed books and pamphlets germane to its purposes and operations as a philanthropic foundation. On July 1, 1951, the Fund entered into an arrangement by which HARVARD UNIVERSITY PRESS became the publisher of Commonwealth Fund books, assuming responsibility for their production and distribution. The Fund continues to sponsor and edit its books, and cooperates with the Press in all phases of manufacture and distribution.

\title{
Distributed in Great Britain \\ By Oxford University Press \\ London
}

LIBRARY OF CONGRESS CATALOG CARD NO. 60-5739

MANUFACTURED IN THE UNITED STATES OF AMERICA 


\section{THE STUDY STAFF}

\section{FOR THE STUDY AS A WHOLE}

Ray E. Trussell, M.D., M.P.H., F.A.P.H.A., Director of the Study

JACK ElInson, PH.D., Senior Study Director, National Opinion Research Center

Patricia Collette, M.A., Assistant Study Director, National Opinion Research Center

Edmund D. Pellegrino, M.D., Director of Internal Medicine, Hunterdon Medical Center

Andrew D. Hunt, JR., M.D., Director of Pediatrics, Hunterdon Medical Center

\section{FOR SPECIAL ASPECTS}

\section{Community Self-Survey Phase}

Eric Groezinger, M.A., formerly County Superintendent of Schools; and teachers and students (for mapping and census-taking)

Mrs. Harry W. Moore and citizen volunteers from the Community Council of the Medical Center (for distributing and collecting self-administered questionnaires)

David E. Ryan, Field Supervisor, National Opinion Research Center (for development of self-administered questionnaire and training of enumerators and supervisors)

Marguerite F. Hall, PH.D.; Anne Halkovich, M.B.A.; F. Herbert Colwell, DR.P.H., New Jersey State Department of Health (for supervision of the collection, coding, and tabulation of self-administered questionnaires)

\section{Family Interview Phase}

David E. Ryan; Mardean Ryan; and Patricia Collette, M.A.; field supervisors of National Opinion Research Center's interviewing staff

Marguerite F. Hall, PH.D.; Esther Wollin, M.P.H.; F. Herbert Colwell, DR.P.H.; John Young; New Jersey State Department of Health

For supervision of the coding and tabulation of family interview schedules

\section{Medical Verification Phase}

Marjorie Yard, Medical Record Librarian, Hunterdon Medical Center Esther Wollin, M.P.H., New Jersey State Department of Health

\section{Clinical Evaluation Phase}

Evaluation Staff:

Pauline R. Goger, PH.D., M.D., internist

Robert R. Henderson, M.D., internist

Andrew D. Hunt, Jr., M.D., pediatrician

David S. Sanders, M.D., pediatrician

Beatrice S. Tileston, M.s.s., social worker

Gertrude M. Loos, M.A., social worker 
Phyllis S. Mann, M.S.w., social worker

Margaret B. Wiles, R.N., M.A., public health nurse

Vocational rehabilitation consultants, State of New Jersey

\section{Sample Recruitment:}

Mrs. Harry W. Moore

Mrs. Richard de Rochemont

Gertrude M. Loos, M.A.

Beatrice S. Tileston, M.s.S.

Belle Parmet, M.A.

\section{Consultants:}

Carl W. Roessel, M.D., surgeon

Herman W. Rannels, M.D., obstetrician and gynecologist

Donald A. Fonda, M.D., opthalmologist

Walter A. Petryshn, M.D., otolaryngologist

Miriam Reed, M.D., dermatologist

Edward E. P. Seidmon, M.D., allergist

Morris Parmet, M.D., psychiatrist

Alexander Mitchell, M.D., urologist

Albert B. Accetolla, M.D., orthopedist

Frederick J. Knocke, M.D., orthopedist

Stephan B. Dewing, M.D., radiologist

Edwin V. Olmstead, M.D., pathologist

Eloise O. Myers, PH.D., psychologist

\section{Multiple Screening Phase}

Technicians and volunteers (Captain, Mrs. Mary Hart)

Advisory Commirtee (General Survey Objectives and Design; Family Interview Phase)

Morton L. Levin, M.D., Assistant Commissioner of Health, New York State Health Department and formerly Director, Commission on Chronic Illness

Clark L. Tibbitts, United States Public Health Service

Wilson Wing, M.D., M.P.H., Johns Hopkins University School of Hygiene and Public Health

Selwyn Collins, PH.D., United States Public Health Service

Frederick F. Stephan, Professor of Statistics, Princeton University

Ad Hoc Advisory Commitree (Clinical Evaluation Phase)

Howard Rusk, M.D. (Chairman) 